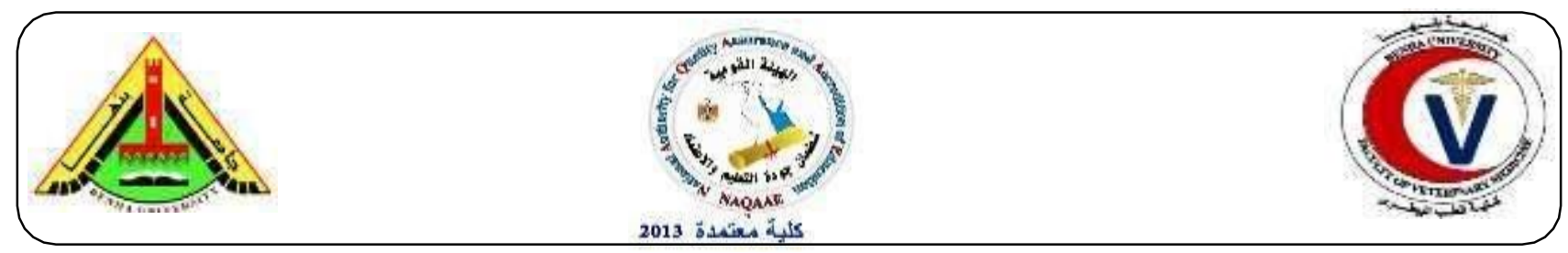

\title{
Detection of shiga toxin strains of Escherichia coli non 0157 in different soft cheese by polymerase chain reaction
}

\author{
Naglaa M. Taha ${ }^{1}$, Hend A. Elbarbary ${ }^{2}$ Ekbal M. A. Ibrahim ${ }^{2}$, , Hamdi A. Mohammed ${ }^{2}$ and Nahed \\ M. M. Wahba ${ }^{1}$
}

${ }^{1}$ Food Hygiene Department, Faculty of Veterinary Medicine, Moshtohor, Benha University.

${ }^{2}$ Food Hygiene Department, Animal Health Research Institute, Assiut. Egypt.

\section{A B S T R A C T}

The objectives of the current study were detection and characterization of the isolated Escherichia coli non O157 using PCR assay. A total of 90 cheese samples high salt soft cheese, Kareish cheese and Tallaga cheese were examined for E. coli non $\mathrm{O} 157$ using modified vancomycin- trypticase soy broth and Sorbitol MacConkey agar plates. Serodiagnosis of E. coli non-O157 has been done using slide agglutination test. Toxigenic E. coli non-O157 isolates were detected using PCR assay. Results postulated that the detection rate of non $\mathrm{O} 157$ using biochemical technique was $63.33 \%$ in Kariesh cheese, $20 \%$ in high salt soft cheese cheese, and $33.33 \%$ in Tallaga cheese. Ten different serotypes of E. coli non O157 have been distributed as following O1 (4.44\%), O18 (1.11\%), O20 (1.11\%), O25 (1.11\%), O26 (3.33\%), O125 (1.11\%), O126 (1.11\%), O127 (1.11\%) and untyped E. coli (18.89\%). Regarding PCR results, serotypes group (O1) was positive for Stx2 gene, (O1 and O20) were positive for both Stx2 and hly genes, one serotype group O25 was positive for eaeA gene, one serotype group $\mathrm{O} 26$ was positive for hly gene while no detection for Stx1and STa genes. From the aforementioned data, attention must be paid to the problems of E. coli non $\mathrm{O} 157$ in foods. Consequently, more restriction and preventive measures should be taken in milk herds, milk production and dairy factories in respect to quality control sanitation and health care.

Keywords: E. coli non-O157, Stx1, Stx2, eaeA and hly genes .

(http://www.bvmj.bu.edu.eg)

(BVMJ-36(2): 353-359, 2019)

\section{INTRODUCTION}

Diarrheaogenic E. coli (DEC) are some of the most frequently detected pathogens worldwide. There are six pathotypes of DEC: Enterotoxigenic E. coli (ETEC), Entero-aggregative E. coli (EAEC), Entero-pathogenic E.coli (EPEC), Enteroinvasive E. coli (EIEC), Enterohaemorrhagic E. coli (EHEC) or Verocytotoxinproducing E. coli and diffusely adherent E. coli (Bischoff et al., 2005 ; Vernacchio et al., 2006). Although many strains of non-O157 STEC appear to be less virulent than E. coli O157:H7. In 2008 an outbreak of STEC strain O111 in Oklahoma caused illness in at least 314 people, HUS in 17 cases, and one death (Mathusa et al., 2010).

Shiga toxins, the main virulence factors contributing to pathogenicity consist of two major types, Stx1 and Stx2, each including several variants (Scheutz and Strockbine, 2005). Non O157 Shiga toxin-producing E. coli (STEC) strains have been linked to outbreaks and 
sporadic cases of illness worldwide. Illnesses linked to STEC serotypes other than O157:H7 appear to be on the rise in the United States and worldwide, indicating that some of these organisms may be emerging pathogens (Mathusa et al., 2010).

Cheeses were contaminated with different STEC serotypes $(\mathrm{O} 26: \mathrm{H} 11, \mathrm{O} 103: \mathrm{H} 2$ and $\mathrm{O} 145: \mathrm{H} 28)$ at the milk preparation stage. STEC growth and survival were monitored on selective media during the entire manufacturing process. (Miszczycha et al., 2013).

\section{MATERIALS AND METHODS}

\subsection{Samples collection:}

Ninety soft cheese samples divided as Kareish cheese, high salt soft cheese and Tallaga cheese(30 of each) were collected from milk vendors and retail shops from Assuit Governorate, Egypt for detection of shiga toxin strains of Escherichia coli non 0157 in different soft cheese by polymerase chain reaction.

\subsection{Isolation and identification of E. coli non} O157: Samples were prepared to isolate the E. coli according to standard Bacteriological Analytical Manual (BAM), U.S. Food and Drug Administration (USFDA) method (Kumar et al., 2008). The samples were enriched in modified vancomycin- trypticase soy broth (MVTSB) and incubated at $37^{\circ} \mathrm{C}$ for $24 \mathrm{~h}$. (Samadpouret al., 1990). Loopful of culture inoculated into Sorbitol MacConkey (SMAC) agar plates and incubated at $37^{\circ} \mathrm{C}$ for $24 \mathrm{~h}$. Suspected E. coli O157 colonies were sorbitol negative and appeared pale in colour as compared with bright pink sorbitol positive, these colonies produced by E. coli nonO157 and other enteric pathogens (De Boer and Heuvelink, 2000).Various biochemical tests were done for the confirmation of E. coli non-O157 as proposed by APHA (1992).

2.3. Serodiagnosis of E. coli non-O157:

It had been done in Clinical Microbiology unit in Central Health Laboratories of Ministry of Health and Serology unit in Animal Health Research Institute, Cairo, Egypt. The test sera/test reagents anti-coli intended for use in the serological detection was purchased from SIFIN (Institut für Immunpräparate und Nährmedien GmbH Berlin, Germay). The determination of the serovar E. coli strains isolated from soft cheese samples were done using slide agglutination test. The test sera are absorbed sera from immunized rabbits. The test reagents consist of a mixture of absorbed sera from immunized rabbits and monoclonal antibodies or contain only monoclonal antibodies.

2.4. Detection of toxigenic E. coli non-O157 isolates using PCR assay:

It had been done in Biotechnology unit in Animal Health Research Institute, Cairo, Egypt. Cycling conditions of the primers during PCR are shown in Table (1).Primers were supplied from metabion (Germany).They have specific sequence and amplify specific products as illustrated in Table (2).

Table (1): Cycling conditions of the primers during PCR.

\begin{tabular}{rccllll}
\hline Target gene & $\begin{array}{c}\text { Primary } \\
\text { denaturation }\end{array}$ & $\begin{array}{c}\text { Secondary } \\
\text { denaturation }\end{array}$ & Annealing & Extension & $\begin{array}{r}\text { No. of } \\
\text { cycles }\end{array}$ & $\begin{array}{c}\text { Final } \\
\text { extension }\end{array}$ \\
\hline Stxl & $94^{\circ} \mathrm{C}$ & $94^{\circ} \mathrm{C}$ & $58^{\circ} \mathrm{C}$ & $72^{\circ} \mathrm{C}$ & 35 & $72^{\circ} \mathrm{C}$ \\
& $5 \mathrm{~min}$. & $30 \mathrm{sec}$. & $45 \mathrm{sec}$. & $45 \mathrm{sec}$. & & $10 \mathrm{~min}$. \\
Stx2 & $94^{\circ} \mathrm{C}$ & $94^{\circ} \mathrm{C}$ & $58^{\circ} \mathrm{C}$ & $72^{\circ} \mathrm{C}$ & 35 & $72^{\circ} \mathrm{C}$ \\
& $5 \mathrm{~min}$. & $30 \mathrm{sec}$. & $45 \mathrm{sec}$. & $45 \mathrm{sec}$. & & $10 \mathrm{~min}$. \\
& $94^{\circ} \mathrm{C}$ & $94^{\circ} \mathrm{C}$ & $60^{\circ} \mathrm{C}$ & $72^{\circ} \mathrm{C}$ & 35 & $72^{\circ} \mathrm{C}$ \\
& $5 \mathrm{~min}$. & $30 \mathrm{sec}$. & $50 \mathrm{sec}$. & $1 \mathrm{~min}$. & & $10 \mathrm{~min}$. \\
& $94^{\circ} \mathrm{C}$ & $94^{\circ} \mathrm{C}$ & $57^{\circ} \mathrm{C}$ & $72^{\circ} \mathrm{C}$ & 35 & $72^{\circ} \mathrm{C}$ \\
& $5 \mathrm{~min}$. & $30 \mathrm{sec}$. & $30 \mathrm{sec}$. & $30 \mathrm{sec}$. & & $7 \mathrm{~min}$. \\
& $94^{\circ} \mathrm{C}$ & $94^{\circ} \mathrm{C}$ & $51^{\circ} \mathrm{C}$ & $72^{\circ} \mathrm{C}$ & 35 & $72^{\circ} \mathrm{C}$ \\
& $5 \mathrm{~min}$. & $30 \mathrm{sec}$. & $30 \mathrm{sec}$. & $30 \mathrm{sec}$. & & $7 \mathrm{~min}$. \\
\hline
\end{tabular}


Table (2): Oligonucleotide primers encoding for 16SrRNA and clfA genes.

\begin{tabular}{|c|c|c|c|}
\hline Target gene & $\begin{array}{l}\text { Primer sequence } \\
\quad\left(5^{\prime}-3^{\prime}\right)\end{array}$ & $\begin{array}{l}\text { Length of amplified } \\
\text { product }\end{array}$ & Reference \\
\hline Stx1 & $\begin{array}{l}\text { ACACTGGATGATCTCAGTGG } \\
\text { CTGAATCCCCCTCCATTATG }\end{array}$ & $614 \mathrm{bp}$ & $\begin{array}{l}\text { Dipineto } e t \\
\text { al., } 2006\end{array}$ \\
\hline Stx 2 & $\begin{array}{l}\text { CCATGACAACGGACAGCAGTT } \\
\text { CCTGTCAACTGAGCAGCACTTTG }\end{array}$ & 779 bp & \\
\hline Hly & $\begin{array}{l}\text { AACAAGGATAAGCACTGTTCTGGCT } \\
\text { ACCATATAAGCGGTCATTCCCGTCA }\end{array}$ & 1177 bp & $\begin{array}{l}\text { Piva et al., } \\
\quad 2003\end{array}$ \\
\hline$S T a$ & $\begin{array}{l}\text { GAAACAACATGACGGGAGGT } \\
\text { GCACAGGCAGGATTACAACA }\end{array}$ & $229 \mathrm{bp}$ & $\begin{array}{l}\text { Lee } \text { et al., } \\
\quad 2008\end{array}$ \\
\hline$e a e A$ & $\begin{array}{l}\text { ATG CTT AGT GCT GGT TTA GG } \\
\text { GCC TTC ATC ATT TCG CTT TC }\end{array}$ & $248 \mathrm{bp}$ & $\begin{array}{c}\text { Bisi- } \\
\text { Johnson et } \\
\text { al., } 2011\end{array}$ \\
\hline
\end{tabular}

\section{RESULTS}

Results postulated in Table (3) indicated that the detection rate of E. coli non O157 using biochemical reactions was $63.33 \%$ in Kareish cheese, $20 \%$ in high salt soft cheese and $33.33 \%$ in Tallaga cheese.

Serological identification of isolated E. coli declared that the highly contaminated product was Kareish cheese (53.33\%) followed by Tallaga cheese $(30 \%)$ and high salt soft cheese $(16.67 \%)$ (Table 4). Ten different serotypes of E. coli non $\mathrm{O} 157$ have been distributed as following
O1 (4.44\%), O18 (1.11\%), O20 (1.11\%), O25 (1.11\%), O26 (3.33\%), O125 (1.11\%), O126 $(1.11 \%), \mathrm{O} 127(1.11 \%)$ and untyped E. coli (18.89\%) (Table 5). Regarding PCR results, E. coli non $\mathrm{O} 157$ was detected in 5 out of 90 samples $(5.56 \%)$ distributed as $10 \%$ in Kareish cheese and $6.67 \%$ in Tallaga cheese (Table 6). Serotypes group (O1) was positive for Stx2 gene, (O1 and O20) were positive for both Stx 2 and hly genes, one serotype group $\mathrm{O} 25$ was positive for eaeA gene, one serotype group $\mathrm{O} 26$ was positive for hly gene while no detection for Stx1and STa genes(Table 7).

Table (3): Incidence of E.coli non $\mathrm{O} 157$ in the examined cheese samples based on biochemical reactions.

\begin{tabular}{cccc}
\hline Samples & No. of examined samples & No. of positive samples & $\%$ \\
\hline Kareish cheese & 30 & 19 & 63.33 \\
High salt soft cheese & 30 & 6 & 20 \\
Tallaga cheese & 30 & 10 & 33.33 \\
Total & 90 & 35 & 38.89 \\
\hline
\end{tabular}

Table (4): Incidence of E.coli non O157 in the examined cheese samples based on serology.

\begin{tabular}{cccc}
\hline Samples & $\begin{array}{c}\text { No. of examined } \\
\text { samples }\end{array}$ & No. of positive samples & $\%$ \\
\hline Kareish cheese & 30 & 16 & 53.33 \\
High salt soft cheese & 30 & 5 & 16.67 \\
Tallaga cheese & 30 & 9 & 30 \\
Total & 90 & 30 & 33.33 \\
\hline
\end{tabular}


Table (5): Serological differentiation of E. coli non $\mathrm{O} 157$ in the examined cheese samples.(n=30)

\begin{tabular}{|c|c|c|c|c|c|c|c|c|c|c|c|c|c|c|c|c|c|c|}
\hline \multirow[t]{2}{*}{ Samples } & \multicolumn{2}{|c|}{$\begin{array}{c}\text { E. coli } \\
\text { O1 }\end{array}$} & \multicolumn{2}{|c|}{$\begin{array}{c}\text { E. coli } \\
\text { O18 }\end{array}$} & \multicolumn{2}{|c|}{$\begin{array}{c}\text { E. coli } \\
\text { O20 }\end{array}$} & \multicolumn{2}{|c|}{$\begin{array}{c}\text { E. coli } \\
\text { O25 }\end{array}$} & \multicolumn{2}{|c|}{$\begin{array}{c}\text { E. coli } \\
\text { O26 }\end{array}$} & \multicolumn{2}{|c|}{$\begin{array}{l}\text { E. coli } \\
\text { O125 }\end{array}$} & \multicolumn{2}{|c|}{$\begin{array}{l}\text { E. coli } \\
\text { O126 }\end{array}$} & \multicolumn{2}{|c|}{$\begin{array}{l}\text { E. coli } \\
\text { O127 }\end{array}$} & \multicolumn{2}{|c|}{$\begin{array}{l}\text { Untyped } \\
\text { E. coli }\end{array}$} \\
\hline & $\mathrm{N}$ & $\%$ & $\mathrm{~N}$ & $\%$ & $\mathrm{~N}$ & $\%$ & $\mathrm{~N}$ & $\%$ & $\mathrm{~N}$ & $\%$ & $\mathrm{~N}$ & $\%$ & $N$ & $\%$ & $N$ & $\%$ & $\mathrm{~N}$ & $\%$ \\
\hline $\begin{array}{l}\text { Kareish } \\
\text { cheese }\end{array}$ & 2 & 6.67 & 0 & 0 & 1 & 3.33 & 0 & 0 & 2 & 6.67 & 1 & 3.33 & 0 & 0 & 1 & 3.33 & 9 & 30 \\
\hline $\begin{array}{l}\text { High salt } \\
\text { soft } \\
\text { cheese }\end{array}$ & 2 & 6.67 & 0 & 0 & 0 & 0 & 0 & 0 & 0 & 0 & 0 & 0 & 0 & 0 & 0 & 0 & 3 & 10 \\
\hline $\begin{array}{l}\text { Tallaga } \\
\text { cheese }\end{array}$ & 0 & 0 & 1 & 3.33 & 0 & 0 & 1 & 3.33 & 1 & 3.33 & 0 & 0 & 1 & 3.33 & 0 & 0 & 5 & 16.67 \\
\hline Total & 4 & 4.44 & 1 & 1.11 & 1 & 1.11 & 1 & 1.11 & 3 & 3.33 & 1 & 1.11 & 1 & 1.11 & 1 & 1.11 & 17 & 18.89 \\
\hline
\end{tabular}

Table (6): Incidence of $E$. coli non $O 157$ containing toxigenic genes in the examined cheese samples according to PCR results. $(\mathrm{n}=30)$

\begin{tabular}{cccc}
\hline Samples & No. of examined samples & No. of positive samples & $\%$ \\
\hline Kareish cheese & 30 & 3 & 10 \\
High salt soft cheese & 30 & 0 & 0 \\
Tallaga cheese & 30 & 2 & 6.67 \\
Total & 90 & 5 & 5.56 \\
\hline
\end{tabular}

Table (7): Differentiation of toxigenic genes among the isolated E.coli non O157 strains.

\begin{tabular}{|c|c|c|c|c|c|}
\hline \multirow[t]{2}{*}{ Samples } & \multicolumn{2}{|c|}{$\begin{array}{c}\text { E. coli } \\
\text { O1 }\end{array}$} & \multirow{2}{*}{$\begin{array}{c}\begin{array}{c}\text { E. coli } \\
\text { O20 }\end{array} \\
\text { Stx2 and hly }\end{array}$} & \multirow{2}{*}{$\begin{array}{c}\text { E. coli } \\
\text { O25 } \\
\text { eaeA }\end{array}$} & \multirow{2}{*}{$\begin{array}{c}\text { E. coli } \\
\text { O26 } \\
\text { hly }\end{array}$} \\
\hline & Stx2 & $\begin{array}{c}\text { Stx2 and } \\
\text { hly }\end{array}$ & & & \\
\hline Karish cheese & 1 & 1 & 1 & 0 & 0 \\
\hline $\begin{array}{l}\text { High salt } \\
\text { soft cheese }\end{array}$ & 0 & 0 & 0 & 0 & 0 \\
\hline Tallaga cheese & 0 & 0 & 0 & 1 & 1 \\
\hline
\end{tabular}

\section{DISCUSSION}

Kareish cheese is one of the ancient Egyptian fresh white soft cheeses. It is consumed largely in Egypt due to its low price and high nutritive value. The incidence of E. coli non $\mathrm{O} 157$ was $63.33 \%$ in Kareish cheese, $20 \%$ in high salt soft cheese, $33.33 \%$ in Tallaga cheese (Table 3). The variation between such types of cheeses in results may be due to the difference in salt concentrations, acidity, and the method of manufacture. Additionally, ripening in brine solution, quality and heat treatment of milk used in the manufacture, handling method, hygienic practices, transportation condition, storage condition and distribution play an important role in its microbial quality.

Nearly similar result was detected by El- Bessery (2006).Lower result in kariesh cheese was reported by Hassan and Gomaa (2016). Higher incidence in kariesh cheese was reported by Ombarak et al.(2016) and Amin et al.(2017). 
The higher rate of E. coli contamination rate of Kareish cheese observed is may be due to the differences in cheese making process and the characteristics of final product between cheeses (Ombarak et al., 2016).

Contamination of cheese with micro-organisms may originate from many sources. Such sources during cheese production might be: starter culture, brine, floor and packaging material, cheese vat, cheese cloth and curd cutting knife, cold room and production room air (Sharaf et al., 2014).

Serological identification of isolated E. coli declared that the highly contaminated product was Kareish cheese (53.33\%) followed by Tallaga cheese $(30 \%)$ and high salt soft cheese (16.67\%) (Table 4). These results were not agree with those recorded by Elsherif (2014) who found that the contamination with E. coli in Tallaga cheese samples was $12 \%$. In the current study, the strains of pathogenic E. coli isolated from examined soft cheese were illustrated as $\mathrm{O} 1$ (4.44\%), O18 (1.11\%), O20 (1.11\%), O25 (1.11\%), O26 (3.33\%), O125 (1.11\%), O126 $(1.11 \%), \mathrm{O} 127(1.11 \%)$ and untyped E. coli (18.89\%) as shown in Table (5).

The highest number of E. coli strains isolated from Kareish cheese, 2 strains for each of O1and $\mathrm{O} 26$ (6.67\%), one strain for each of O20, O125 and $0127(3.33 \%)$ and $9(30 \%)$ untyped strains. one strain for each of O18, O25, O26 and O126 (3.33\%) and 5(16.67\%) untyped strains isolated from Tallaga cheese. Two strains belonged to $\mathrm{O} 1$ $(6.67 \%)$ and $3(10 \%)$ untyped strains isolated from high salt soft cheese (Table 5). A large number of STEC strains (e.g., members of the serogroups O26, O91, O103, O111, O118, O145, and O166) have caused major outbreaks and sporadic cases of human illnesses that have ranged from mild diarrhea to the life-threatening hemolytic uremic syndrome (Hussein and Sakuma, 2005).

Different serotypes groups of STEC isolates were detected by PCR from the examined soft cheese. Serotypes group (O1) was positive for Stx2 gene, (O1 and O20) were positive for both Stx 2 and hly genes, one serotype group O25 was positive for eaeA gene, one serotype group $\mathrm{O} 26$ was positive for hly gene while no detection for Stx1 and STa genes (Table 7).

Nearly similar results have been reported by Hassan and Elmalt (2008) in Kareish cheese who showed that one strain encoded for Stx2gene and none for Stx land eaeA. On another hand, out of 50 cheese samples, $4(16.00 \%)$ isolates were positive for Stx1 gene only, while $5(20.00 \%)$ isolates were positive for Stx 2 gene and 2 isolates $(8.00 \%)$ were positive for eaeA gene (Virpari et al., 2013).Other studies detected STEC grew in the two uncooked processed cheeses during the first $24 \mathrm{~h}$ of cheese making Then, STEC levels progressively decreased in cheeses that were ripened for more than 6 months. In lactic cheese with along acidic coagulation step, STEC did not grew (Miszczycha et al., 2013).

Detection of Stx genes or prevalence of E. coli harboring Stx genes in dairy products were reported at various degree from different countries such as $0.45 \%$ in Spain (Quinto and Cepeda, 1997), 0.87\% in Canada (Steele et al., 1997), 3.9\% in Germany (Klie et al., 1997), 6\% in Brazil (Paneto et al., 2007) and13\% in France (Vernozy-Rozand et al., 2005).

\section{CONCLUSION}

High detection rate of non $\mathrm{O} 157$ using biochemical technique was recorded in Kariesh cheese followed by Tallaga cheese and high salt soft cheese. On the other hand PCR results indicated that E. coli non $\mathrm{O} 157$ was detected in 5 out of 90 samples $(5.56 \%)$ soft cheese samples. So, PCR has advantages in terms of sensitivity, specificity, cost and ease of implementation. Multiplex PCR assay presented here is a practical and rapid diagnostic tool for identification of enterotoxigenic E. coli in a single reaction tube. 
From the aforementioned data, attention must be paid to the problems of E. coli non $\mathrm{O} 157$ in foods. Consequently, more restriction and preventive measures should be taken in milk herds, milk production and dairy factories in respect to quality control sanitation and health care. Moreover, a preventive strategy based on thorough analysis of conditions, which ensure that objectives of the quality assurance program are met, is recommended.

\section{REFERENCES}

APHA, 1992. American Public Health Association: Compendium of Methods for the Microbiological Examination of foods. $2^{\text {nd }} E d$., Washington, Dc, USA.

Amin, W.F., Ahmed, E.H., Embarak, M.S., AboShama, U.H., Thabit, A.G., Ismail, S.Y., 2017. Molecular Detection of Enterotoxigenic E. coli in raw Milk and Milk Products International Journal of Current Microbiology and Applied Sciences 6, 856-864.

Bischoff, C., Lüthy, J., Altwegg, M., Baggi, F., 2005. Rapid detection of diarrheagenic E. coli by real-time PCR. Journal of microbiological methods 61, 335-341.

De Boer, E., Heuvelink, A., 2000. Methods for the detection and isolation of Shiga toxin-producing Escherichia coli. Journal of applied microbiology 88, 133S-143S.

El-Bessary, M. 2006. Sanitary status of milk and some milk products marketed in suburbs of Assiut governorate. Thesis, Ph. D. of Veterinary Medicine, University of Assiut, Egypt.

Elsherif, W.M., 2014. Prevalence and significance of non O157 Shiga toxin producing E. coli in milk and some dairy products. Global Journal of Agriculture and Food Safety Sciences 1, 157-167.

Hassan, G.M., Gomaa, S.M., 2016. Microbiological Quality of Soft Cheese Marketed in Cairo and Giza
Governorates. Alexandria Journal for Veterinary Sciences 50,18-23.

Hassan, S., Elmalt, L., 2008. Informally raw milk and kareish cheese investigation on the occurrence of toxigenic Escherichia coli in Qena city, Egypt with emphasis on molecular characterization. Assiut University Bulletin for Environmental Researchs 11, 35-42.

Hussein, H., Sakuma, T., 2005. Invited review: prevalence of Shiga toxin-producing Escherichia coli in dairy cattle and their products. Journal of Dairy Science 88, 450-465.

Klie, H., Timm, M., Richter, H., Gallien, P., Perlberg, K., Steinrück, H., 1997. Detection and occurrence of verotoxinforming and/or shigatoxin producing Escherichia coli (VTEC and/or STEC) in milk. Berliner und Munchener Tierarztliche Wochen-schrift 110, 337341.

Kumar, R., Surendran, P., Thampuran, N., 2008. Evaluation of culture, ELISA and PCR assays for the detection of Salmonella in seafood. Letters in applied microbiology 46, 221-226.

Mathusa, E.C., Chen, Y., Enache, E., Hontz, L., 2010. Non-O157 Shiga toxin-producing Escherichia coli in foods. Journal of food protection 73, 1721-1736.

Miszczycha, S.D., Perrin, F., Ganet, S., Jamet, E., Tenenhaus-Aziza, F., Montel, M.-C., Thevenot-Sergentet, D., 2013. Behavior of different Shiga toxin-producing Escherichia coli serotypes in various experimentally contaminated raw-milk cheeses. Appl. Environ. Microbiol. 79, 150-158.

Ombarak, R.A., Hinenoya, A., Awasthi, S.P., Iguchi, A., Shima, A., Elbagory, A.R.M., Yamasaki, S., 2016.. Prevalence and pathogenic potential of Escherichia coli isolates from raw milk and raw milk 
cheese in Egypt. International journal of food micro-biology 221, 69-76.

Paneto, B., Schocken-Iturrino, R., Macedo, C., Santo, E., Marin, J., 2007. Occurrence of toxigenic Escherichia coli in raw milk cheese in Brazil. Arquivo Brasileiro de Medicina Veterinária e Zootecnia 59, 508-512.

Quinto, E.J., Cepeda, A., 1997. Incidence of toxigenic Escherichia coli in soft cheese made with raw or pasteurized milk. Letters in Applied Microbiology 24, 291 295.

Samadpour, M., Liston, J., Ongerth, J.E., Tarr, P.I., 1990. Evaluation of DNA probes for detection of Shiga-like-toxin-producing Escherichia coli in food and calf fecal samples. Applied Environmental Microbiology 56, 1212-1215.

Scheutz, F., Strockbine, N., 2005. Genus I. Escherichia. Bergey's manual of systematic bacteriology. Springer Publishing Company, New York, NY, p 607-624.

Sharaf, O.M., Ibrahim, G., Tawfek, N.F., Effat, B.A., El Shafei, K., El-Din, E., Salem, M.M., 2014. Prevalence of some pathogenic microorganisms in factories Domiati, Feta cheeses and UHT milk in relation to public health sold under market conditions in Cairo. International Journal of Chem Tech Research 6, 28072814.

Steele, M.L., McNAB, W.B., Poppe, C., Griffiths, M.W.,Chen, S., DeGrandis, S.A., Fruhner, L.C., Larkin, C.A., Lynch, J.A., Odumeru, J.A., 1997. Survey of Ontario bulk tank raw milk for foodborne pathogens. Journal of Food Protection 60, 1341-1346.

Vernacchio, L., Vezina, R.M., Mitchell, A.A., Lesko, S.M., Plaut, A.G., Acheson, D.W., 2006. Diarrhea in American infants and young children in the community setting: incidence, clinical presentation and micro-biology. The Pediatric infectious disease journal 25, 27.

Vernozy-Rozand, C., Montet, M., Berardin, M., Bavai, C., Beutin, L., 2005. Isolation and characterization of Shiga toxin-producing Escherichia coli strains from raw milk cheeses in France. Letters in applied microbiology 41, 235-241.

Virpari, P.K., Nayak, J.B., Brahmbhatt, M.N., Thaker, H.C., 2013. Study on isolation, molecular detection of virulence gene and antibiotic sensitivity pattern of E. coli isolated from milk and milk products. Vet. world, 541-545. 